\title{
THE DEVELOPMENT OF THE POWER GRID IN THE ASPECT OF LOCAL ZONING PLANS
}

\author{
MARCIN KOPICZKO
}

University of Szczecin, Faculty of Management and Economics of Services, POLAND

e-mail: marcin.kopiczko@wzieu.pl

RECEIVED
ACCEPTED
JEL
CLASSIFICATION

KEYWORDS

ABSTRACT
10 December 2018

28 December 2018

013, 014, 018, R11

MPZP, KSE, electrical power, OSD

The development of the power grid is a necessity for satisfying the needs of recipients resulting from economic growth, technological progress and improvement of the living standards of electricity consumers. Distribution system operators implement development plans taking into account the existing local zoning plans (MPZP). The purpose of the publication is to indicate the dependence of the power grid development by the OSD on the developed zoning plans for a given area. The article consists of three basic parts preceded by the introduction and completed with conclusions. The first part of the article presents the principles of spatial policy in Poland. The second part presents an overview of the National Distribution System with particular reference to the Distribution System Operators as the entity responsible for the distribution of electricity. The third part is an attempt to illustrate the dependence of the development of the power grid on the planned development of the area expressed in the Zoning Plan (MPZP). The whole is summarized by conclusions.

\section{Introduction}

The plans for the development of the power grid take into account the current and forecasted increase in electricity demand and security of supply, taking into account the most important information resulting directly from the provisions of local zoning plans or directions of the municipality development defined in the study of conditions and directions for spatial development. 


\section{Local zoning plan}

Spatial policy is an important part of development policy, and its goal is the best and most optimal spatial management. Spatial planning regulations constitute the foundation of investment activities, that is they are decisive for the feasibility of projects and play an important role in the development of modern infrastructure (Polskie Koleje Państwowe SA, 2018).

Spatial planning formulates the principles of land development and enables shaping space in accordance with the needs of residents in a rational, sustainable manner, consistent with the existing local conditions, while maintaining environmental, cultural and landscape values (Budplan sp. z o.0., 2017). Therefore, spatial policy is a translation of the vision of the development of a given area into the language of specific actions, causing the desired changes in the spatial structure in a given territory (Markowski, 1999, p. 168). In order to determine the spatial policy of the commune, including the local spatial development rules, the commune council adopts a resolution on joining the stage of conditions and directions of the spatial development of the commune. A commune head, mayor or city president draws up a stage containing a text and graphic part (a few selected graphic signs are presented in Table 1), taking into account the principles of spatial development of the country, setting development strategy and voivodship development plan, framework study of conditions and directions for spatial development of the metropolitan union and development strategy of the commune, if the municipality has such a study (Ustawa..., 2003).

Table 1. Selected graphic signs used in the drawings of the local zoning plan

\begin{tabular}{lcc}
\hline Single-family housing & MN & Light brown \\
\hline Service buildings & U & Red \\
\hline Agricultural areas & R & Yellow \\
\hline Forests & ZL & Bottle green \\
\hline Greenery areas decorated & ZP & Green \\
\hline Water areas & WS & Light blue \\
\hline Public roads & KD & White \\
\hline Areas of internal roads & KDW & Light gray \\
\hline Electrical Power & E & \\
Water supply & W & Slate \\
Sewers & K & \\
\hline
\end{tabular}

Source: Rozporządzenie Ministra Infrastruktury... (2003).

The shaping of spatial policy in Poland is implemented at several levels: national, voivodship, poviat and commune, in which documents or plans emerging at the lower level take into account provisions created at a higher level, it means superior one. For inhabitants, the most important level is the communal level, on which local zoning plans are created. The local zoning plan (MPZP) is a document built on the basis of a study of the conditions and directions of the spatial development of the commune, that is the study of conditions is a preparation preceding the preparation of a local plan MPZP (the provisions of the LSDP may not differ from the provisions of the study). The local zoning plan is a document aimed at maintaining the spatial and landscape order, as well as indicating the places of development of the commune, city or district of the city. 
One of the most important criteria to be considered in the development of the local zoning plan is to maximize the economic use of the city area, while taking into account the limitations resulting from applicable laws, including environmental and cultural values (Markowski, 1999, p. 168).

The basic information about the local zoning plan drawn up for the commune, city or district of the city are mainly determined by:

- the use of areas and lines delimiting areas with different purposes or different development principles,

- principles of protection and shaping of spatial order,

- principles of environmental protection, nature protection and landscape shaping,

- principles of protection of cultural heritage and monuments, including cultural landscapes, and contemporary cultural goods,

- requirements resulting from the needs of shaping public spaces,

- principles of shaping buildings and indicators of land development, maximum and minimum building intensity as an indicator of total building area in relation to the area of a building plot,

- minimum percentage of biologically active area in relation to the area of a building plot,

- maximum building height,

- the minimum number of parking spaces, including places for parking vehicles provided with a parking card and the manner of their implementation,

- building lines and dimensions of objects,

- boundaries and ways of developing areas or objects subject to protection: mining areas, areas of special flood threat, landslide masses, priority landscapes defined in the landscape audit and voivodeship spatial development plans,

- detailed rules and conditions for merging and dividing real estate covered by the local plan,

- special conditions for the development of land and restrictions in their use, including the prohibition of development,

- the manner and date of temporary management, arrangement and use of land,

- principles of modernization, development and construction of communication systems and technical infrastructure (Miejscowy..., 2017).

The construction of communication systems and technical infrastructure devices means the construction of a road and the construction of underground or ground or water or water, sewage, heating, electric, gas and telecommunications equipment (Ustawa z dnia 21 sierpnia 1997..., 1997).

\section{Electricity distribution system in Poland}

The basic issues related to the generation, transmission and distribution of electricity on a national basis are related to the concept of the National Power System (KSE). Detailed conditions for the operation of the power system in Poland are set out in the Regulation of the Minister of Economy (Rozporządzenie Ministra Gospodarki..., 2007).

The national power system is a multi-layer network structure with different levels of rated voltage and diversified construction (Nowak, 2017). In places acting as nodes (power stations) connecting networks with different levels of rated voltages, located are transformers. These nodes often include generation units that supply the electricity system with electricity. The block diagram of the power system is shown in Figure 1. 


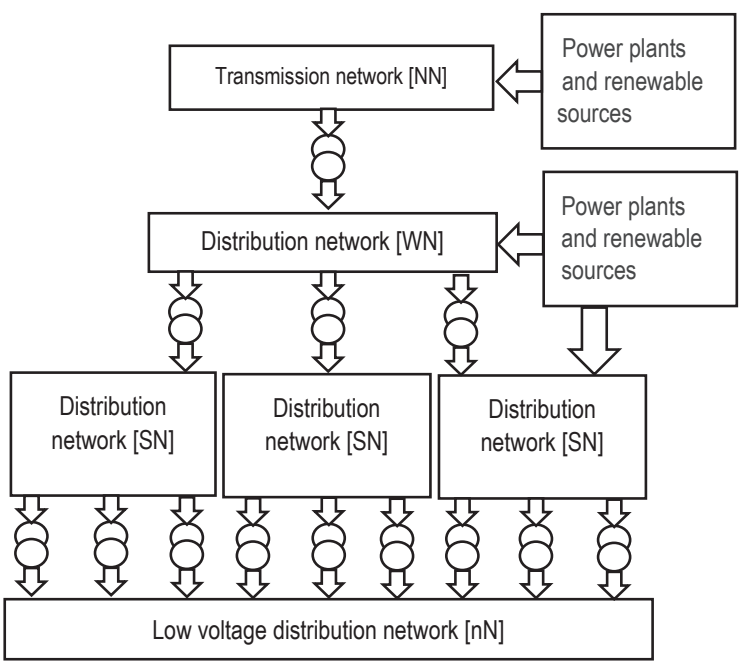

Figure 1. Block diagram of the power system.

Source: own study - developed on the basis of Nowak, Szpyra, Tarko (2017).

The distribution network is a special element of the KSE. Distribution networks are the main link in the power system, whose primary task is to supply electricity that is the basis for the functioning of large enterprises and municipal consumers in large urban agglomerations and villages. The entities responsible for distribution networks are distribution system operators (OSD) dealing with the distribution of electricity, supervision of the proper

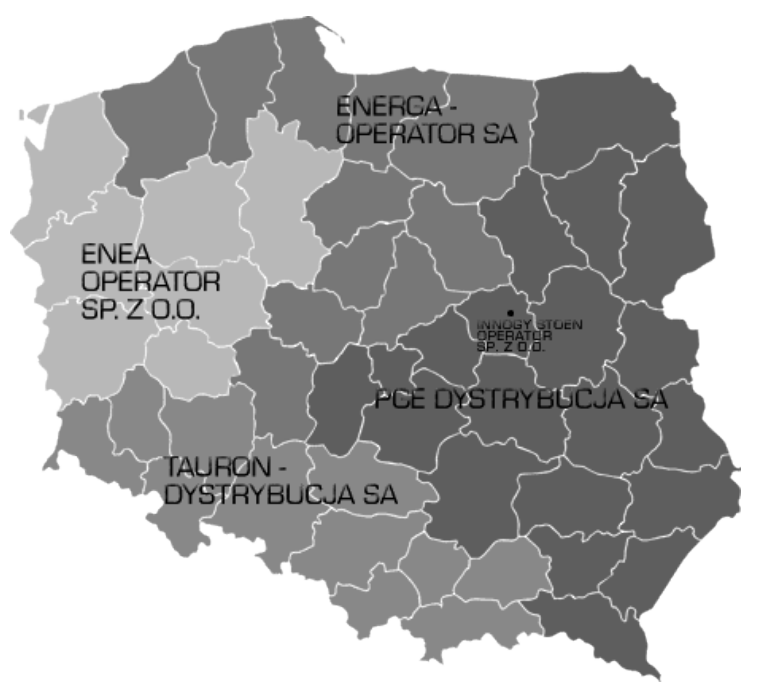

Figure 2. Area of activity of the main OSD in Poland

Source: cire.pl (2018). 
functioning of the system, as well as current and long-term control of the safety of this system. Operators of the distribution system are obliged by the Energy Law Act (Ustawa z dnia 10 kwietnia 1997..., 2017), which also includes the definition of OSD in the energy sector. Figure 2 shows the five largest distribution system operators in Poland, while Table 2 presents the data for each of these operators.

Table 2. Own study - basic data on the five largest OSD in Poland

\begin{tabular}{lcccccc}
\cline { 2 - 7 } & $\begin{array}{c}\text { Number } \\
\text { distributed energy } \\
(\mathrm{MWh})\end{array}$ & $\begin{array}{c}\text { Number } \\
\text { of connections }\end{array}$ & $\begin{array}{c}\text { Number of clients } \\
\text { connected to the } \\
\text { network }\end{array}$ & $\begin{array}{c}\text { Length of electric } \\
\text { power lines } \\
(\mathrm{km})\end{array}$ & $\begin{array}{c}\text { Number } \\
\text { of transformer } \\
\text { stations }\end{array}$ & $\begin{array}{c}\text { Number } \\
\text { of transformers }\end{array}$ \\
\hline ENEA OPERATOR & $19,258,698$ & 840,053 & $2,552,699$ & 104,230 & 37,823 & 37,561 \\
ENERGA OPERATOR & $22,108,918$ & 972,804 & $3,010,730$ & 163,480 & 60,552 & 61,332 \\
$\begin{array}{l}\text { PGE DYSTRYBUCJA } \\
\text { Innogy STOEN }\end{array}$ & $35,313,022$ & $2,972,660$ & $5,350,667$ & 287,992 & 93,488 & 94,281 \\
$\quad \begin{array}{l}\text { OPERATOR } \\
\text { TAURON }\end{array}$ & $7,489,394$ & 98,246 & $1,015,829$ & 15,203 & 6,559 & 6,647 \\
$\quad$ DYSTRYBUCJA & $49,062,591$ & $2,008,075$ & $5,532,681$ & 185,157 & 59,563 & 58,611 \\
\hline
\end{tabular}

Source: Raport Polskiego Towarzystwa... (2018).

Despite the diverse characteristics of the OSD presented, all these entities meet the legal requirements and have the ability to effectively manage their area, in an economically effective manner and ensuring the safety of network users, which is subject to direct supervision by the President of the Energy Regulatory Office (Drożdż, 2018, pp. 291-300).

The number, parameters and status of network assets of individual OSD have a decisive impact not only on the security of the power system, but also on the number and length of interruptions in electricity supply and the possibility of connecting new customers and electricity generators to the electricity grid. The tendency of the increase in receiving and generation power installed in power grids requires the modernization and evolution of existing power facilities, as well as the construction of new power facilities and new strategic sections of power lines for increasing the quality of distribution services by OSD.

\section{Possibilities for the development of the power grid}

With the intensification of the use of devices powered by electricity caused by economic growth, the development of large cities and the increase in the standard of living of individual consumers, there is a need to plan and implement network development in the near and longer term. It is also important for the OSD to ensure the security of the system's operation through appropriate network development, including the expansion of the distribution network, increasing the transmission capacity of this network and enabling the multilateral supply of consumers in the event of a network failure. In the implementation of all types of undertakings, it is also important to estimate the demand for electricity and the planned development of the connected generation sources in the scope of the planned generation of generation capacity (Drożdż, 2018, pp. 291-300). The development of the power grid should be implemented on the basis of the development plans prepared by the OSD in accordance with the provisions of the Energy Law. According to art. $16 \mathrm{sec}$. 1 of this Act, energy enterprises dealing with transmission or distribution of electricity prepare a network development plan in their area of operation, taking into account current 
and future electricity demand, taking into account the provisions of the zoning plan in the discussed area or the directions of the municipality development specified in the study of conditions and directions of spatial development.

Existing power devices are plotted on zoning plans, while new elements of the power grid and connections should be located in places where the Local Zoning Plan or the study of conditions and directions of spatial development allow it. Increasingly, it turns out that these documents clearly prohibit the location of overhead power lines, and allow the construction of underground cable lines, which is primarily aimed at optimizing the development of the area, and the construction of power cable lines will allow the OSD to shorten the interruptions in electricity supply and reduce costs of reconstruction of power infrastructure after the occurrence of weather anomalies, to which the network located above the ground is the most exposed.

Locations of electrical power equipment marked on the graphic works with the symbol "E", to ensure the continuity of electricity supply and to ensure the appropriate quality parameters of electricity, should be located near public or internal roads and in the vicinity of areas foreseen in the MPZP for the construction of industrial or service facilities, and in the central parts of clusters of plots designated for housing development.

\section{Conclusions}

Optimal space management, according to the needs of residents, is the basis for the possibility of implementing projects and developing modern infrastructure. The key role here is played by distribution system operators who, through their development plans, locate new power infrastructure, taking into account the current and future electricity demand, primarily in accordance with zoning plans or a study of conditions and directions for spatial development. All of these activities are aimed primarily at preserving Poland's environmental, cultural and landscape values.

\section{References}

Budplan sp. z o.o. (2017). Czym jest planowanie przestrzenne. Retrieved from: http://www.budplan.net/blog/czym-jest-planowanieprzestrzenne.

Cire.pl (2018). Operatorzy systemów dystrybucyjnych. Retrieved from: https://rynek-energii-elektrycznej.cire.pl/st,33,201,tr,69,0,0,0, $0,0,0$ sd.html.

Drożdż, W. (2018). Operator system dystrybucji w dobie wyzwań innowacyjnej energetyki. Zeszyty Naukowe Instytutu Gospodarki Surowcami Mineralnymi i Energią PAN, 102, 291-300.

Markowski, T. (1999). Zarządzanie rozwojem miast. Warszawa: Wydawnictwo Naukowe PWN.

Miejscowy Plan zagospodarowania przestrzennego (2017). Retrieved from: https://geoportal360.pl/miejscowy-plan-zagospodarowaniaprzestrzennego.

Nowak, W., Szpyra, W., Tarko, R. (2017). Stan i potrzeby rozwojowe sieci elektroenergetycznych w procesie transformacji niskoemisyjnej w Polsce. Europejski Instytut Miedzi Copper Alliance. Retrieved from: https://leonardo-energy.pl/wp-content/uploads/2017/04/ Stan-i-potrzeby-rozwojowe-sieci-elektroenergetycznych-w-Polsce_pro.pdf.

PolskieKolejePaństwoweSA(2018).Zagospodarowanie przestrzenne. Retrievedfrom:http://www.pkp.pl/pl/wspolpraca-z-samorzadami/ zagospodarowanie-przestrzenne.

Raport Polskiego Towarzystwa 2018 - Polskie Towarzystwo Przesyłu i Rozdziału Energii Elektrycznej (2018). Energetyka, Dystrybucja i Przesył, Poznań. Retrieved from: www.ptpiree.pl/_examples/raport_2018/ raport_ptpiree.pdf.

Rozporządzenie Ministra Gospodarki z dnia 4 maja 2007 r. w sprawie szczegółowych warunków funkcjonowania systemu elektroenergetycznego Dz.U. no. 93, item 623 with changes. 
Rozporządzenie Ministra Infrastruktury z dnia 26 sierpnia 2003 r. w sprawie wymaganego zakresu projektu miejscowego planu zagospodarowania przestrzennego, Dz.U. no. 164, item 1587.

Ustawa z dnia 10 kwietnia 1997 r. Prawo energetyczne, Dz.U. no. 54, item 348 with changes.

Ustawa z dnia 21 sierpnia 1997 r. o gospodarce nieruchomościami, Dz.U. no. 115, item 741.

Ustawa z dnia 27 marca 2003 r. o planowaniu i zagospodarowaniu przestrzennym, Dz.U. 2017, item. 1073 with changes.

Cite this article aS: Kopiczko, M. (2018). The development of the power grid in the aspect of local zoning plans. European Journal of Service Management, 4 (28/2), 215-221. DOI: 10.18276/ejsm.2018.28/2-27. 